\title{
鋼管矢板井筒静的水平抵抗の有限要素解析 \\ FINITE ELEMENT ANALYSIS OF A WELL FOUNDATION COMPOSED \\ OF STEEL PIPES UNDER STATIC LATERAL LOAD
}

\author{
木寺謙爾* ・長岡弘明** ・島岡久寿*** 小 間憲彦**** \\ By Kenji KIDERA, Hiroaki NAGAOKA, Hisatoshi \\ SHIMAOKA and Norihiko KOMA
}

\section{1.まえがき}

鋼管矢板井筒は群杭とケーソンの中間の剛性を持つ基 礎として近年数多く用いられている.この基礎は, 円形 状, 小判状, 長方形状等化打込まれた鋼管, 鋼管相互を 連結している継手，鋼管頭部が埋込まれ剛結されている 鉄筋コンクリートフーチングより成っており，鋼管群は 継手とフーチングにより筒状に一体化されている. 力学 的挙動を明らかにするため模型実験, 実物実験が数多く なされているが末解明の点が多く, 杭基礎に比べて設計 上不確かな点の多い基礎である.

本報告の目的は, 静的な水平荷重を加えられた鋼管矢 板井筒 (以下井筒と略称する) を有限要素でモデル化し, 数值解析により, いまだ実験では明確にされていない性 状, 実験では明確にしにくい性状の一部を明らかにしよ うとすることである. 鋼管は各 1 本を引張および曲汸剛 性を持つ線材要素で, 鋼管相互を結ぶ継手は等価なせん 断剛性を持つ平面応力板有限要素で, 井筒内部および外 部の地盤は三次元立体有限要素で表わし, 三次元弾塑性 問題として解析を行っている。解析結果より, 地盤と井 筒の変形, 鋼管の軸力と曲げモーメント, 継手のせん断 力等についての特性を示している. 次いで, これらの特 性を比較的良く表わし得る簡単な計算式として, 前提条 件が未検証の提案式である駒田・岡原の式 ${ }^{1), 2}$ が妥当で あることを示し, この式と現行設計法 ${ }^{3)}$ の関係, 合成効 率の新しい力学的意味等を論じている. また, 静的挙動 を取り扱った本報告に続き, 動的挙動の解析を別の報 告4)で行っている.

\footnotetext{
* 正会員 日本鋼管 (株) 鉄鋼技術部課長

** 正会員 工博 日本鋼管 (株) 技術研究所倸長

*** 正会員 日本鋼管（株）建材条鋼営業部

**** 正会員 工修 日本鋼管（株）鉄鋼技術部
}

\section{2. 鋼管矢板井筒の概要}

文献 5）で静的水平載荷試験結果が報告されている鋼 管矢板井筒を解析対象とするが，解析の都合上，基礎の 形状に若干の変更が行われている. 図一1 (a) に平面図 で示すように, 井筒は $\mathrm{AA}^{\prime}$ について対称に 2 基設置さ れており，鉄筋コンクリートフーチングは $\mathrm{AA}^{\prime}$ で切離 されている. 外径 $812.8 \mathrm{~mm}$, 厚さ $19 \mathrm{~mm}$ の鋼管が半 径 $4.376 \mathrm{~mm}$ の円周上に 30 本打込まれており, 鋼管頭 部はフーチングに埋込まれ，剛結されている.鋼管相互 を連結する継手は二港建型と言われるもので，空隙はセ メントモルタルでグラウトされている(図一1 (c) 参照). $\mathrm{CC}^{\prime}$ 方向に見た井筒の立面図と土質柱状図を 図一1 (b) に示す. 井筒は脚付型と言われるもので, 深さ $25.5 \mathrm{~m}$ までは継手で一体となった通常の井筒部を成し，25.5 $36.0 \mathrm{~m}$ では 1 本おきにのみ鋼管が打込まれ，いわゆる 脚部を成している.上部の粘土層は液性限界 $w_{L}=80$ . $100 \%$, 塑性指数 $I_{P}=50 \sim 60 \%$ で，塑性図上では高塑性 の無機質粘土に属している. 図一1 に示すように地表面 上の井筒の中心に原点を持ち, 鉛直上方に $z$ 軸, フーチ ング長手方向に $x$ 軸を持つデカルト直交座標系 $x, y, z$ 抢よび円筒座標系 $r, \theta, z$ を用いる.

\section{3. 鋼管矢板井筒の有限要素モデル化}

\section{（1）基礎各部のモデル化}

鋼管は引張剛性, 曲げ岡性を持つ弾性線材要素で表わ す. 継手のこれらの剛性への影響を考虑に入れ， $r$ 方向 の軸について断面二次モーメント $I_{1}=4.79 \times 10^{-3} \mathrm{~m}^{4}, \theta$ 方向の軸について断面二次 モーメント $I_{2}=3.73 \times 10^{-3}$ $\mathrm{m}^{4}$, 断面積 $A=5.23 \times 10^{-2} \mathrm{~m}^{2}$, ヤング率 $E=2.1 \times 10^{7} \mathrm{t} /$ $\mathrm{m}^{2}$ を用いる. 線材は頭部で剛体のフーチングに剛結さ 


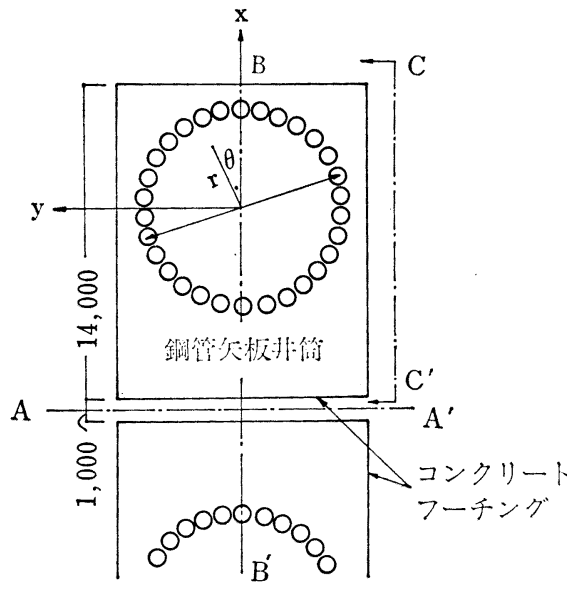

(a) 平面因

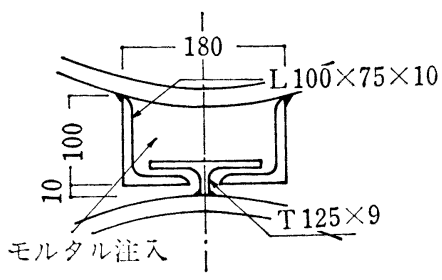

(c) 継 手 部

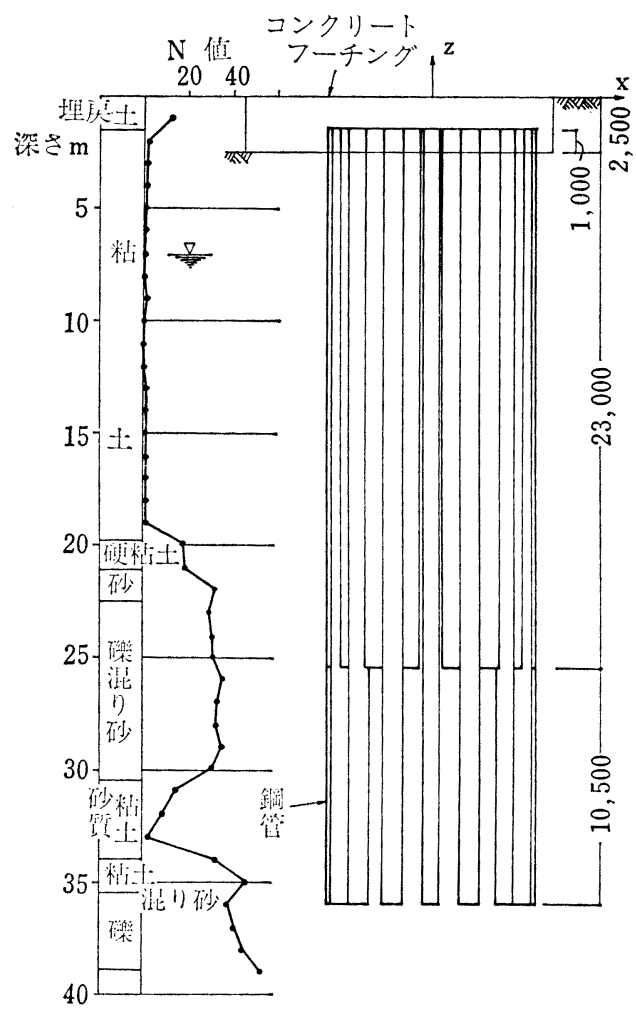

(b) 立面因

図一1 鋼管矢板井筒基礎

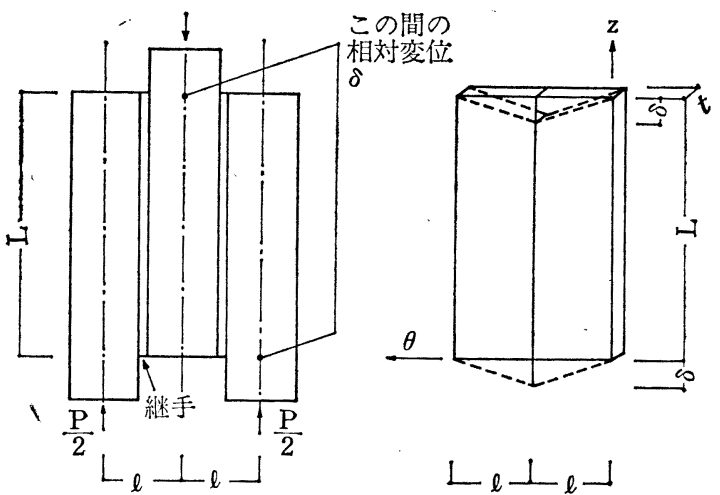

(a) モデル化

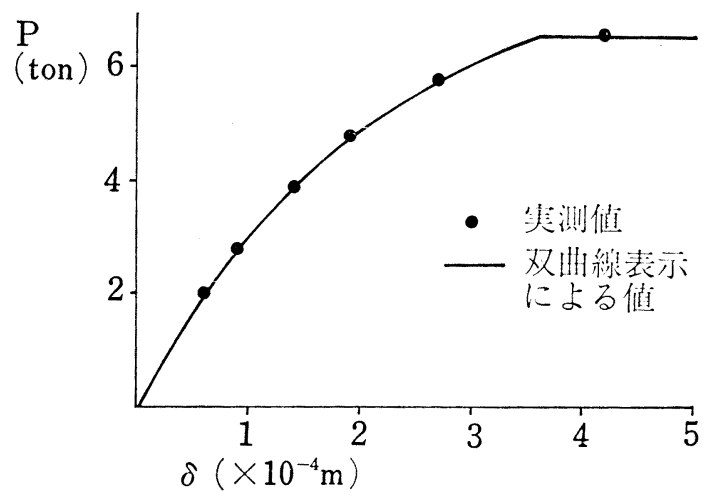

(b) 世ん断試験

図一2 継手部のせん断剛性

れている.

継手は等価なせん断剛性および水平方向の引張剛性を 持つ平面応力板有限要素で表わす.

3 本の鋼管とその間の継手を図一2 (a) に示す. 継手 の長さ $L(\mathrm{~m})$, 鋼管閒隔を $l(\mathrm{~m})$ とする. 中央の鋼管 に荷重 $P$ (ton) を作用させた時, 継手に相対変位 $\delta$ （m）が生じたとする．この継手のせん断剛性と等価な 剛性を持つ平面応力板有限要素を同図に示す. 板厚を $t$ (m) とすると, 平面応力板有限要素のせん断応力 $\tau_{z \theta}$,
せん断ひずみ $r_{z \theta}$, 接線せん断係数 $G_{t}$ は次式で表わさ れる。

$$
\tau_{z \theta}=P / 2 L t, \gamma_{z \theta}=\delta / l, G_{t}=d \tau_{z 0} / d \gamma_{z \theta}
$$

$$
(1 \cdot a, b, c)
$$

鋼管部分について図一2 (a) のそれを若干修正し, 継手 の長さを $L=0.3 \mathrm{~m}$ とした実験を行ったが, これより得 られた荷重 $P$ と相対変位 $\delta$ の関係を図一2 (b) に示寸. 荷重 $P$ が強度 $P_{\max }$ に達するまでは, 次の地盤の応力 ひずみ関係でのべる双曲線関係(6)に従い，強度に達する 
と $P$ は一定值 $P_{\max }$ を保つとする関倸式を用いると， 実験結果は次式で近似できる。

$$
\begin{aligned}
P= & \delta /\left(2.40 \times 10^{-5}+0.0867 \delta\right) \\
& \left(P \leqq P_{\max }\right), P_{\max }=6.50 \text { ton } \cdots \cdots(2 \cdot \mathrm{a}, \mathrm{b})
\end{aligned}
$$

この式による曲線を 図一2 (b) に実線で示す.

図一3に示すように，鋼管の継手位置に水平線荷重 $(\mathrm{t} / \mathrm{m})$ が作用している時の加力点間の相対変位 $\delta$ は, リ ングの弾性問題として求めることができる. 厚さ $t$ の等 価な板の水平方向の引張応力 $\sigma_{\theta}$, 引張ひずみ $\varepsilon_{\theta}$, 弾性倸 数 $E_{\theta}$ は次式で与えられる.

$$
\sigma_{\theta}=w / t, \varepsilon_{\theta}=\delta / l, E_{\theta}=\sigma_{\theta} / \varepsilon_{\theta} \cdots \cdots \cdots \cdots \cdot(3 \cdot \mathrm{a}, \mathrm{b}, \mathrm{c})
$$

実験で用いた 鋼管について求めると $E_{\theta}=1.26 \times 10^{4} \cdot \mathrm{t} /$ $\mathrm{m}^{2}$ である。

継手の縦軸方向（ $z$ 方向）の引張剛性は線材要素の引 張剛性にすで注入れてあるので，平面応力板有限要素 にはその剛性は組入れない，したがって平面応力板有限 要素の接線せん断係数注式 (1) で, $\theta$ 方向の引張に対す る弾性保数は式 (3) で与えられ, 要素は $z$ 方向に引張 剛性を持たない.

地盤はくさび形の五面体または六面体の三次元立体有 限要素でモデル化する. 上部の砂質埋戻土, 粘土につい ては Duncan と Chang の双曲線表示による弾塑性応力 〜ひずみ関倸的を用いる．接線ヤング係数 $E_{t}$, 強度の $50 \%$ の応力での割線ヤング係数いわゆる変形係数 $E_{s}$ は 次式で表わされる (図一4 参照).

$$
\begin{aligned}
& E_{t}=\left(1-R_{f} r\right)^{2} E_{i}, r<1 \\
& E_{t}=0, r=1 \\
& r=(1-\sin \phi)\left(\sigma_{1}-\sigma_{3}\right) /\left(2 c \cos \phi+2 \sigma_{3} \sin \phi\right) \\
& E_{s}=\left(1-0.5 R_{f}\right) E_{i}
\end{aligned}
$$

$\phi$ は内部摩擦角, $c$ は粘着力, $\sigma_{1}, \sigma_{3}$ は最大, 最小主応 力, $E_{i}$ は初期ヤング係数である. $R_{f}$ は土が破壊する時 の最大主応力差 $\sigma_{1}-\sigma_{3}$ を双曲線表示による 終局主応力 差 $\sigma_{1}-\sigma_{3}$ で割った值で 1 に近い值である. さらに砂質 土の初期ヤング係数 $E_{i}$ は次式で与えられる.

$$
E_{i}=K \sigma_{3}{ }^{n}
$$

粘土層では試料採取の際の摚乱が大きく, 良好な一軸圧 縮試験結果が得られなかったため, 文献 5) で報告され ている地盤化類似ではあるが，以下にのべる土質定数を 持つ仮想地盤について解析を行う.

砂質の埋戻土では単位体積重量 $r=1.9 \mathrm{t} / \mathrm{m}^{3}$ と仮定す る. 式 (4)，(5)の $n, R_{f}$ およびポアソン比 $\nu$ は文献 6)，7）の砂質土の例を参考にして決めている. 内部摩 擦角 $\phi$ の決定は, $N$ 值より推定する大崎の式 ${ }^{8)}$ 亿よ。 ている. 式 (5) の $K$ については, まず変形係数を $E_{s}$ $\left.=70 N^{8}\right)$ 上り求め, 次いでこの值が式 $(4 \cdot \mathrm{d}),(5)$ で計 算される $E_{s}$ とほぼ一致するように， $K$ を選んでいる.
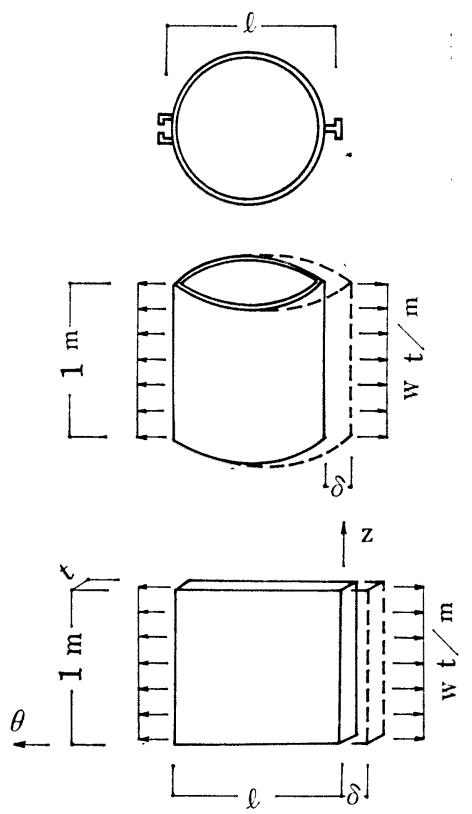

图一3 鋼管の水平方向引張剛性

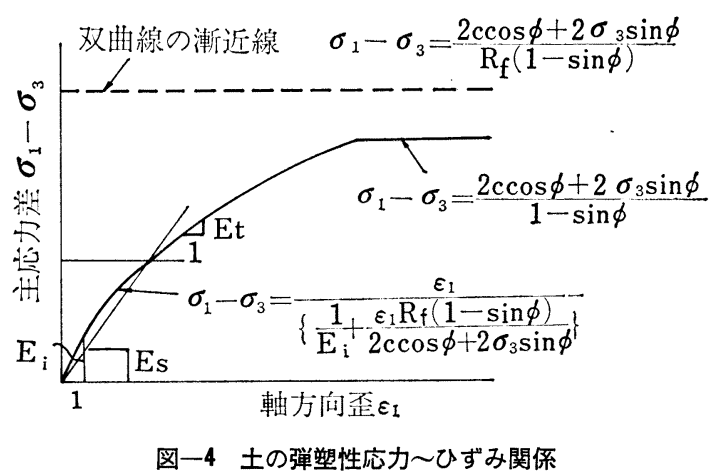

結果として，この解析に採用した砂質埋戻土の諸定数を 次式に示寸.

$$
\left.\begin{array}{l}
\nu=0.3, \phi=30^{\circ}, n=0.6 \\
K=900, R_{f}=0.9, c=0
\end{array}\right\}
$$

粘土層では, 単位体積重量 $r$ として実測值 $1.6 \mathrm{t} / \mathrm{m}^{3}$ を用いる. 式 (4) の $R_{f}$ は文献 7) の例を参考にして 決めている. 飽和粘土は殆んど非圧縮性であり, ポアソ ン比ンは 0.5 に近い值と考えられるが，ここでは計算プ ログラム上の制限から $\nu=0.48$ とする. 粘着力 $c$ として 非排水せん断強度 $c_{u}$ を用いるが, $c_{u}$ は塑性指数 $I_{p}$ と 有効上載圧 $\sigma_{z}{ }^{\prime}$ より推定する ${ }^{9}$. 初期弾性係数 $E_{i}$ につ いては, 変形倸数 $E_{s}$ が非排水せ几断強度 $c_{u}$ の 200 400 倍であること ${ }^{10)}$ と式 $(4 \cdot \mathrm{d})$ より,$E_{i}=400 c_{u}$ の関 倸を用いる. 結果として採用した粘土層の諸定数, 関係 式を次式に示す.

$$
c=0.3 \sigma_{z^{\prime}} E_{i}=120 \sigma_{z^{\prime}} \phi=0, R_{f}=0.9
$$




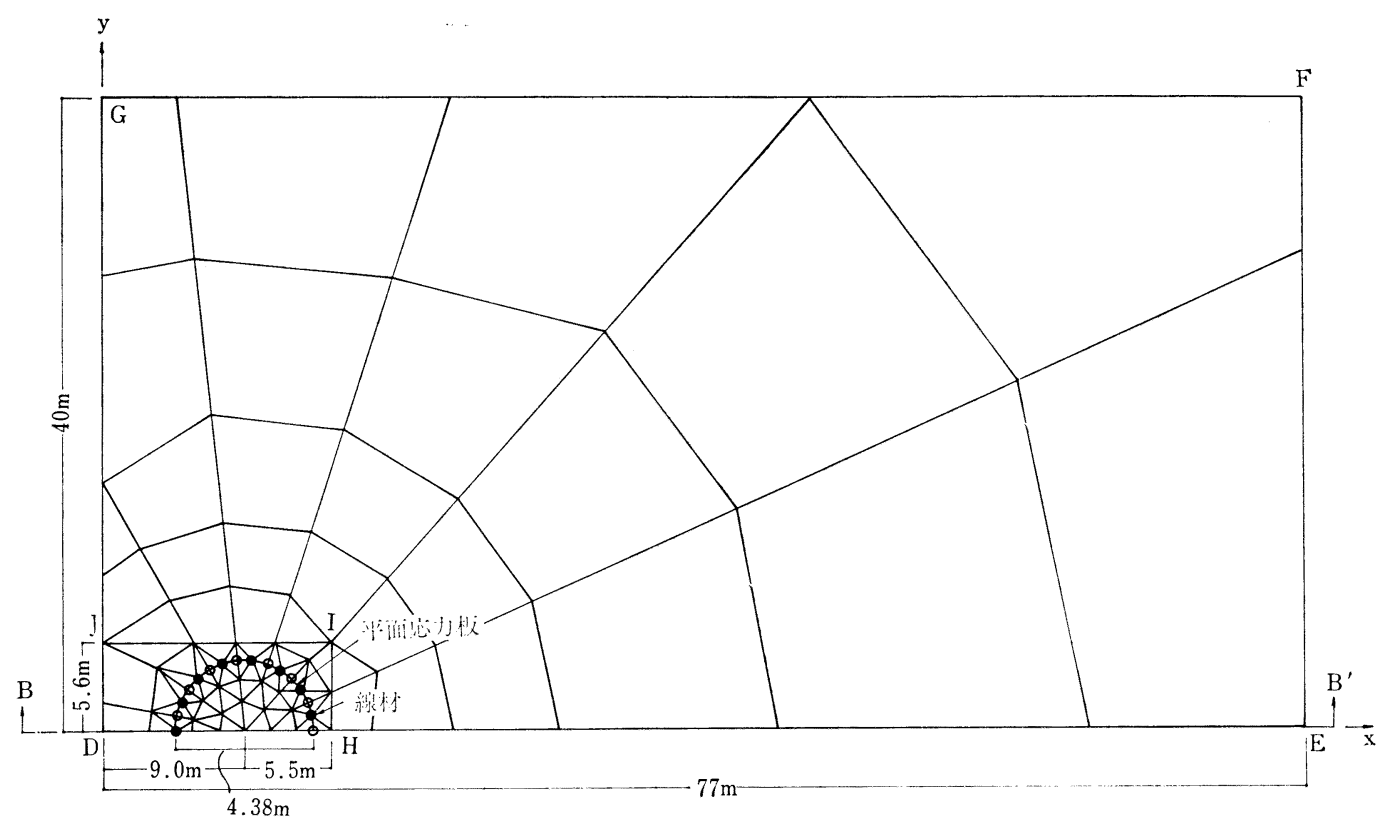

(a) 平面図

軟弱な粘土層の下にある各層については, 生じるひず みが小さいことからヤング係数 $E=130 \mathrm{~N}\left(\mathrm{t} / \mathrm{m}^{2}\right)$ の線 形弾性体とする.このヤング係数は, $E_{s}=70 \mathrm{~N}\left(\mathrm{t} / \mathrm{m}^{2}\right)^{8)}$, $R_{f}=0.9$ として, 式 $(4 \cdot \mathrm{d})$ より求めた初期ヤング係数 $E_{i}$ に近い值である. 支持層のポアソン比は粘土で 0.48 , 砂で 0.3 とする.

\section{（2）基礎全体の有限要素分割}

水平力荷重は図一1 (a)の 2 つのフーチングの間 $\mathrm{AA}^{\prime}$ でフーチング表面より $1.5 \mathrm{~m}$ 下の位置にジャッキで加 えられている. 変形は $\mathrm{AA}^{\prime}, \mathrm{BB}^{\prime}$ の鉛直面について対称 であり，図一5 に示す $1 / 4$ のモデルで解析することがで きる. 図一5 (a) は深さ $2.5 \sim 25.5 \mathrm{~m}$ での任意の深さの 水平面上の有限要素分割を表わしている. 白丸, 黒丸は 線材を示し, その間を継手である平面応力板有限要素が 連結している (図一6 参照). 水平面上の地盤の有限要 素分割は深さによって変らないが，深さ $0 \sim 2.5 \mathrm{~m}$ では DHIJ 部分がコンクリートフーチングにおきかわり， 25.5 36 m の脚部では線材が 1 本抢きに黒丸の位置に のみあり, 継手は存在しない. 図一5 (a) の $\mathrm{BB}^{\prime}$ 断面図 を図一5 (b) に示す.

対称条件から DE, DG の鉛直面上で面に直交する方 向の変位成分を零とするが, DG 鉛直面上の節点におい ては, 初期圧縮応力状態から変化し引張応力が生じる と, き裂が生じたとみなして, 以後の荷重増分に対し $x$ 方向の節点变位の拘束を切離す.フーチング底面の $z$ 方 向初期接触圧は同一梁さの土被り上載圧に等しいとし, 引張応力が生じるとフーチング と地盤の間に 空隙が生

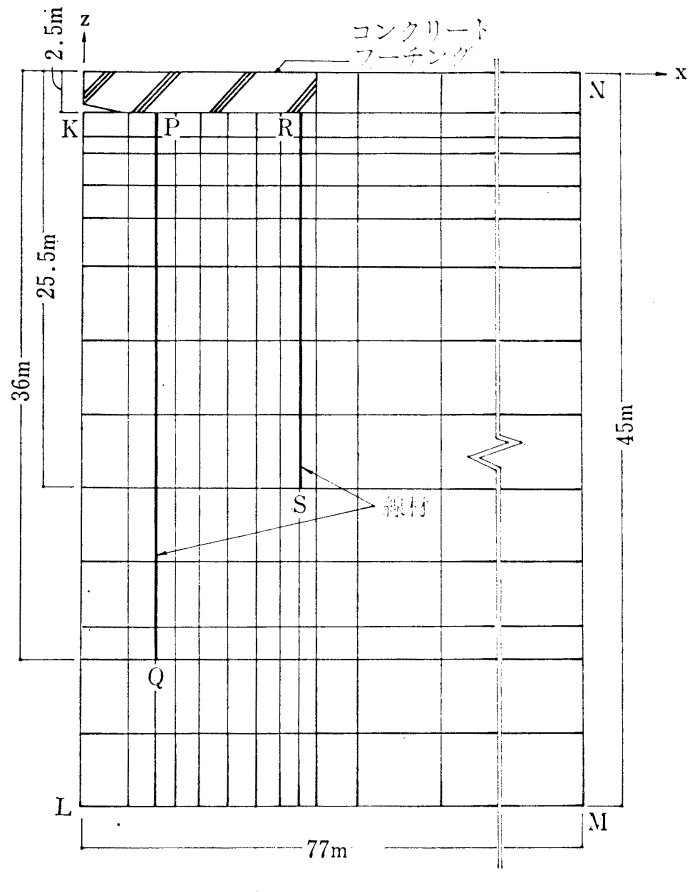

(b) 断 面 因

\section{図一5 有限 要素分 割}

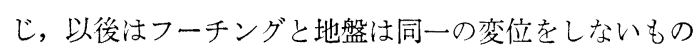
とする. 粘性土では多少の引張抵抗を持つものと思われ るが,ここでは無視している.

荷重の増加により, 鋼管側面, フーチング側面, フー チング 底面での摩擦力が摩擦抵抗に 等しくなると, 以 後, 地盤との間にすべりが生じるものとする，粘性土の 


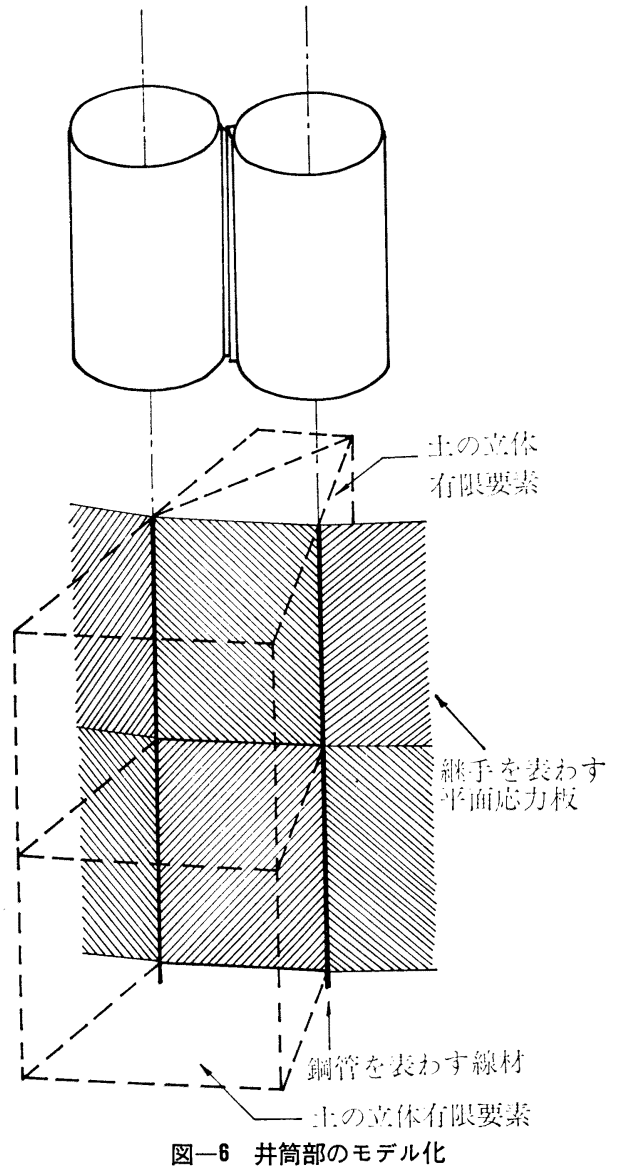

摩擦抵抗として非排水せん断強度 $c_{u}$ を用いる. 砂質埋 戻土の摩擦抵抗として, 構造物と接触している面へ地盤 がおよぼす圧縮直応力に $\tan \phi$ を乘じた值とする.なお 実際の計算では，すべりが生じた後の直応力の増加は小 さかったので, すべりが生じた後の摩擦抵抗は, すべり 始めた時の值を保つものとしている.

これらのき裂や空隙の判定, 摩擦力の評価は接触面上 節点の節点力を用いて行う.

荷重増分間で接線弾性係数を一定とし, 増分解を求め る, いわゆる増分法 ${ }^{6)}{ }^{77}$ により弾塑性計算を行う.この 解析例では, 総末知数が約 4000 と多いため, 荷重増分 を小さくすることが計算時間上困難であり，荷重は 400 , 800,1200，1600 ton の 4 段階とする. 荷重が 0 400 ton での接線係数 $E_{t}, G_{t}$ (式 (2)，(4)) はひずみが零 の時の值を用いている. 400 ton 以降について, 荷重が $P$ から $P+\Delta P$ に増加する際の接線弾性係数の評価, 摩 擦力が最大值に達しているか否かの判定, フーチング底 面に空隙が生じるか否かの判定，および DG 鉛直面で き裂が生じるか否かの判定は，次のように行う。図一7 に示すように, 荷重が前段階 $P-\Delta P$ から現段階 $P$ に増 えた時, 応力または節点力は $S-\Delta S$ から $S$ になったと

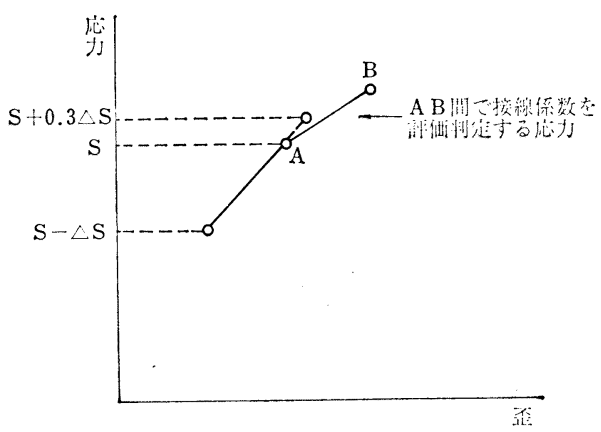

図-7 接線係数の評価に用いる応力

する. 荷重が $P$ から次の段階 $P+\Delta P$ に増加する時の上 記の評価・判定は，文献 6)，7）で行われたように $S$ の 值で行うことと, 次の段階で応力または節点力が $S+\Delta S$ になると仮定して, 中央での值 $S+0.5 \Delta S$ で行うこと が考えられる.ここでは便宜上, 両者の中間の值である $S+0.3 \Delta S$ で評価・判定を行う.このため, 地盤や継手 が計算上降伏したとみなされる時の強度は, 与えられた 強度と多少異なる值となっている.

以上は, 井筒全体の挙動の把握を主目的としているた め, 鋼管を線材でモデル化している. 実際の鋼管は薄肉 の円筒であり, 線材モデルでは表わせない状態が考えら れる. その問題点のいくつかをあげると，

(i) フーチングとの接合部近傍で, 線材モデルでは 表わせないシェルとしての応力が鋼管に生じてい る.

(ii） 継手からくるせん断力そのほかにより, (i) と 同様にシェルとしての応力が鋼管に生じている.

(iii) 線材モデルでは, 図一1（a）に示す井筒中心を 原点とした時の $\theta$ 方向の鋼管引張剛性は, 図一3 に示すように取り入れられているが，これに直交 する $r$ 方向の鋼管の引張剛性は 無限大としてい る. 実際にはこの剛性は有限である.

（iv）線材モデルでは鋼管先端が支持地盤に点で接し ているが，実際には先端位置で鋼管および鋼管内 部の土が有限の面積で接している. これらの点については，今後研究を進めていきたい.

\section{4. 解析結果についての検討と考察}

\section{（1）荷重～変位曲線}

2 基の井筒の実測および計算水平変位について, 荷重 ～変位・弾性変位・残留変位曲線を図一8 に示す. 計算 弾性変位曲線として文献 11) に示される方法に従い, 初 期係数に対する荷重〜変位曲線，すなわち荷重 0 ～400 ton 間の割線を 400 ton 以上の荷重に延長したものを 
用いている. 2 基の井筒の内, よ り剛な挙動をする井筒の変位は 800 ton まで, より柔な挙動をす る井筒では 400 ton まで, 計算結 果と実験結果のよい一致が見られ る. それら以上の荷重に対しては いずれも計算結果がより剛な挙動 を示している.このことは, 解析 に用いた上部粘土層の初期弾性係 数は現地盤のそれを比較的よく表 わしているが，せん断強度は現地 盤のそれより過大であることを示 しているものと思われる.

以後の検討においては, 評価し た土質定数が現地盤のそれと異な っていると思われるため計算值と 実測值の対比は行わず， 3. で示 した土質定数を持つ仮想の地盤内 の井筒としてその挙動特性を考察 する.

仮想地盤の場合について, 設計施工指針) に基づいて 求めた井筒頭部自由の場合の常時および地震時荷重〜変 位関係を図一8 に示す.ここでは井筒部を 10 節点, 脚



図一9 対称断面上鋼管の変位


図一8 荷 重 変 位曲 線

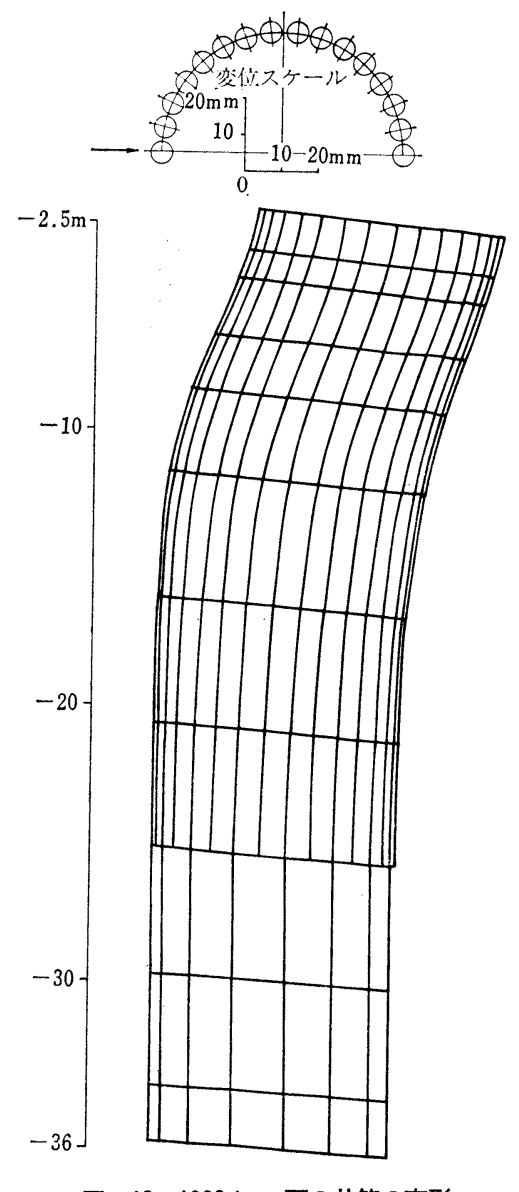

図-10 1600 ton 下の井筒の変形 


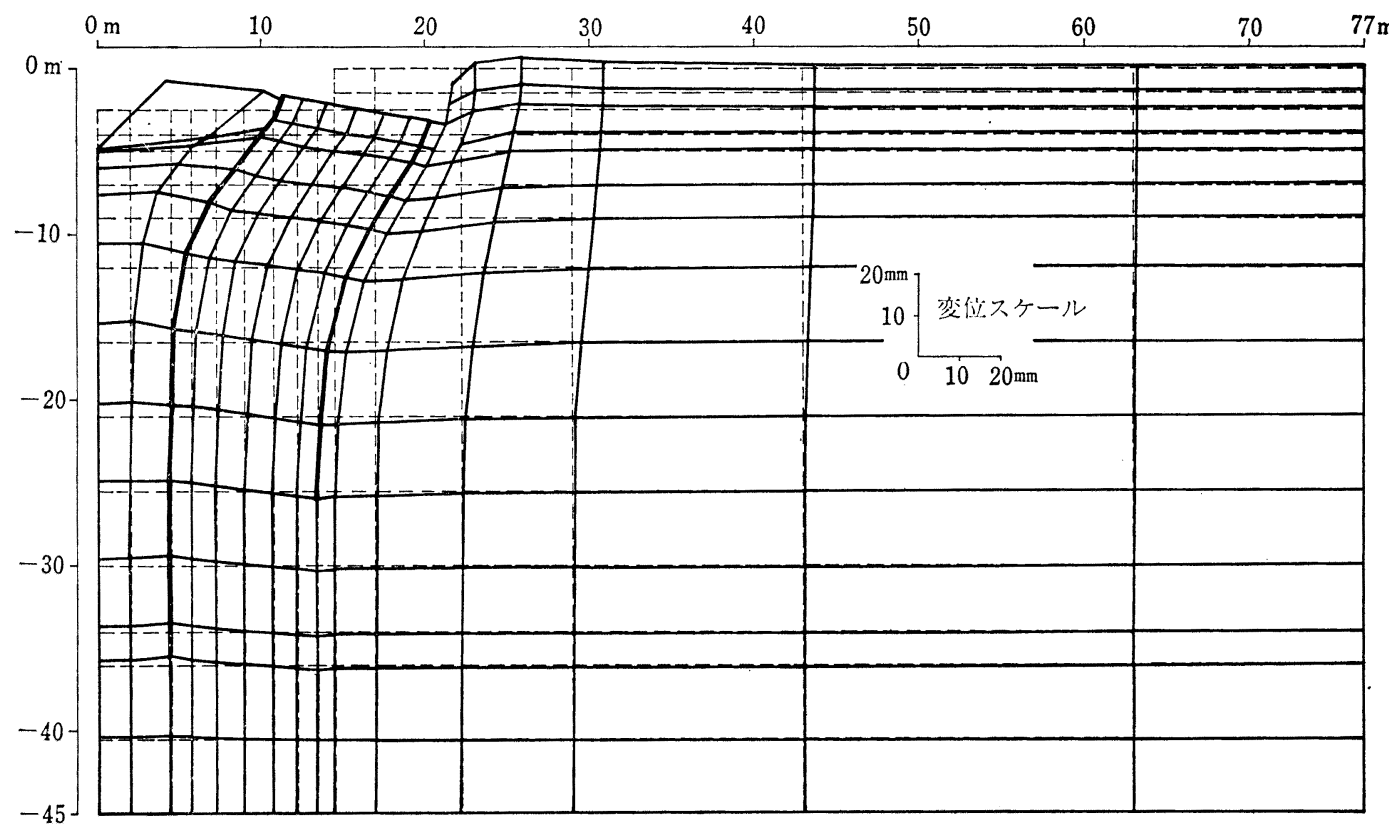

図一11 1600 ton 下の地盤の変形

部を 4 節点で分割している. 埋戻土層, 上部粘土層のば ね係数は, 式 (4) で計算した变形係数 $E_{s}$ を一軸圧縮試 験またはボーリング孔内で測定した值として求め, それ より下部の層のばね係数は $N$ 值より求めている. 地震 時荷重について指針の方法で求めた荷重〜变位関倸は, 有限要素法による関係と荷重 800 ton までほぼ一致して いる. 常時荷重について指針の方法で求めた関係の勾配 は，有限要素法による関係の 800 1600 ton での平均 勾配とほぼ一致している.

\section{（2）井筒および地盤の変位}

荷重 400, 800, 1200,1600 ton での対称断面上の 2 本の鋼管およびフーチングの変位を図一9に, 1600 ton での井筒の変形および対称断面上の地盤の変形を図一 10,11 に示寸. 井筒自体は各鋼管矢板が連結されている とはいえ, 比較的変形しやすく, 剛なケーソンよりはむ しろフーチングで頭部を剛結された群杭に近い剛性を持 っているものと思われる. 井筒の変形はせん断変形のあ るはりの変形に類似しており, 中心軸に变形前直交して いた平面は，変形後も平面を保っているが，中心軸とは 直交していない，井筒内部の土も同様にほぼ平面を保持 し，鋼管群と大体同一の変位をしている. 地盤の変形図 より, フーチング底面での空隙, 左側にある鋼管の上部 と地盤の間のすべり，地盤の左上部の引張き裂等を見る ことができる.

\section{（3）鋼管の軸力および曲げモーメント}

対称断面上の 2 本の 鋼管の曲げモーメントを図一12

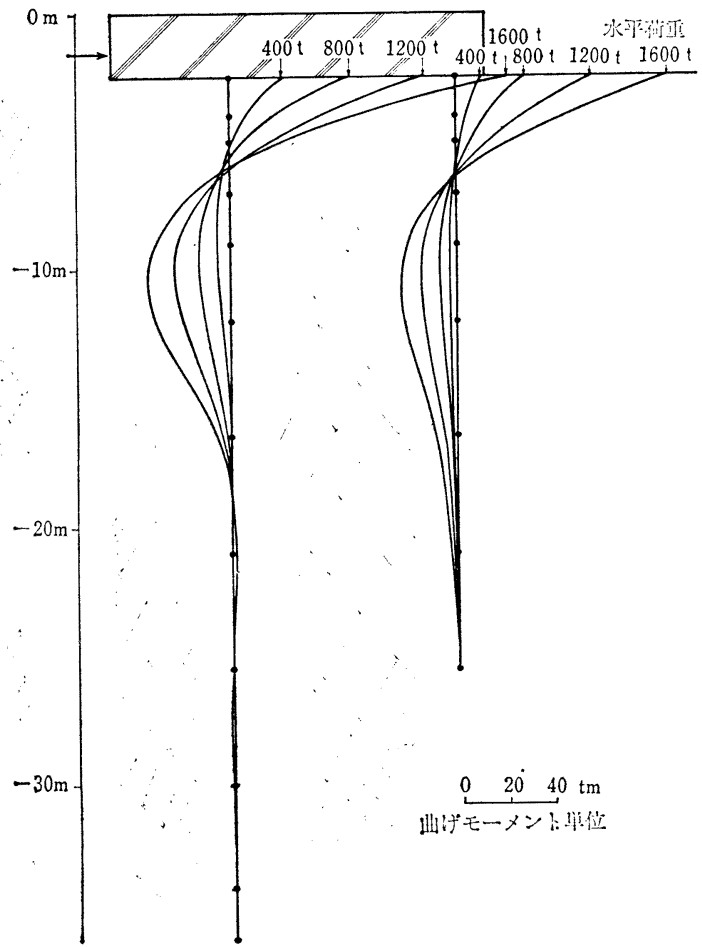

図一12 対称断面上鋼管の曲げモーメント

に示す.ここでは示していないが，他の鋼管の $y$ 軸まわ り曲げモーメント分布形は, 対称断面上の 2 本のそれに 類似しており，鋼管位置による分布形の大きな相異は見 られなかった。

各荷重での 対称断面上の 2 本の 鋼管の軸力を図-13 
に, 1600 ton での 7 本の鋼管のそれを図一14 亿示す. 曲げモーメントと異なり, 軸力は各鋼管ごとに傾向の異 なる鉛直方向分布形をしている. 対称断面上にある 2 本 の鋼管軸力は頭部において,左の鋼管で圧縮, 右の鋼管で 引張を示し, 深さ方向の勾配は $14 \mathrm{~m}$ 以浅で特異な傾向 を示している.この現象は次のことより生じたものと推 察することができる．鋼管に作用する鉛直力は上下端を 除くと外部抒よび内部の土からの摩擦力と継手からのせ ん断力である. 図一11の鋼管に接する土のせん断変形 から推定した摩擦力の作用方向と, 後述の継手のせん断 力から決めたせん断力の作用方向を 図一15 (a) に示寸. 図一13 の軸力分布の勾配より求めた, 摩擦力とせん断 力の合力の作用方向を 図一15 (b) に示す.この図より， 上記軸力分布の特異な現象は内部の土からの摩擦力およ び継手からのせん断力により生じたことが推察される. 対称断面上の 2 本の鋼管から離れるにつれて軸力勾配の 特異性は小さくなっているが存在し，同様の推察をする ことができる. 深さ $28 \mathrm{~m}$ 付近で，対称断面上の鋼管お よびそれに近い数本の鋼管では軸力勾配が不規則になっ ている.これは $25.5 \mathrm{~m}$ 以深では長鋼管のみが 1 本おき に配置され，短鋼管および継手部がなくなったため生じ た現象と思われる。
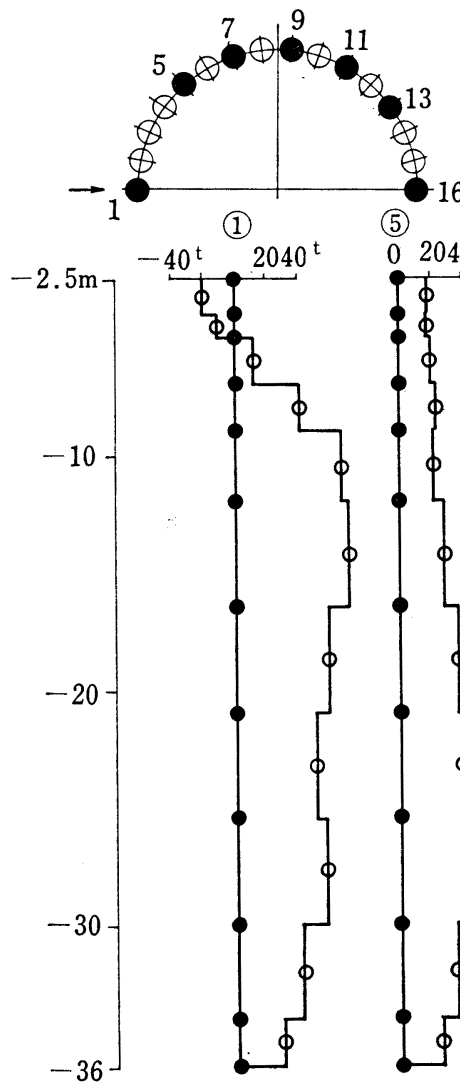

(7)

(9)

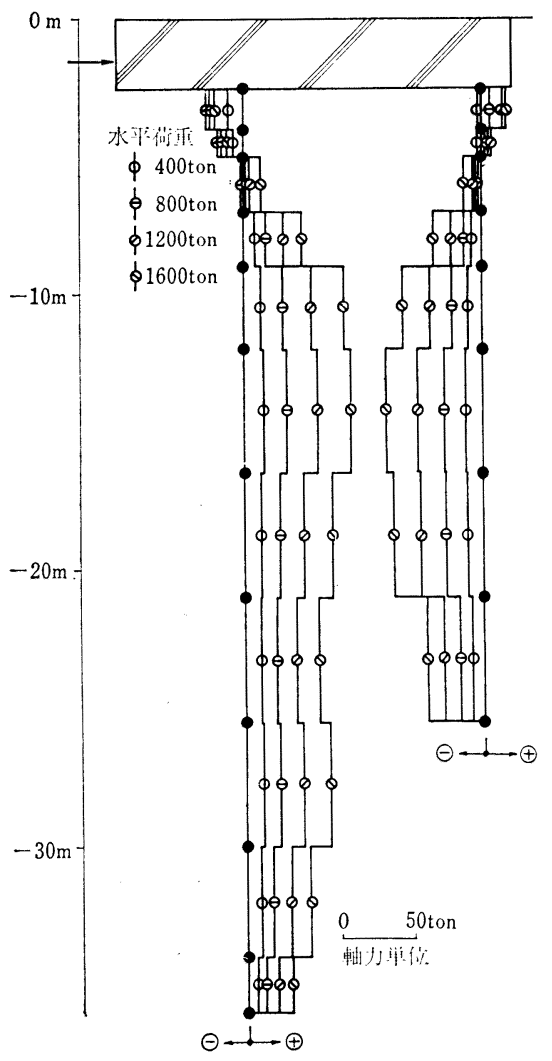

図一13 対称断面上鋼管の軸力

$-20^{\mathrm{t}}$
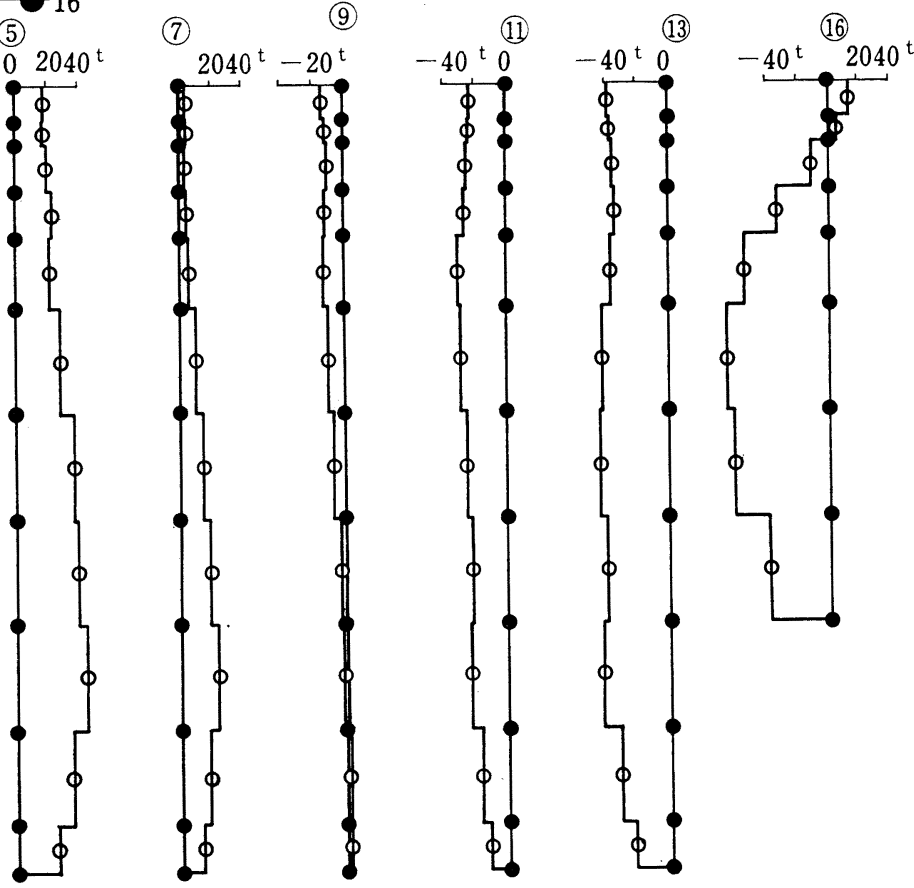

図-14 1600 ton下の鋼管軸力 


\section{（4）継手のせん断力}

継手のせん断力分布を図一16に示す．2．でのべた計 算法を用いたため, 計算によるせん断降伏力は真の降伏 值 $10.8 \mathrm{t} / \mathrm{m}$ を中心に最大 2 割の範囲にちらばっている. 荷重 400 800 ton の間ですでに降伏が始まっており， 1600 ton に達すると上部は殁んど降伏し，下部の未降 伏領域でも降伏值に近い值になっている．継手が比較的 早く, しかも広範囲にせん断降伏することから，継手の せん断剛性注あまり期待できず，鋼管矢板井筒の挙動は

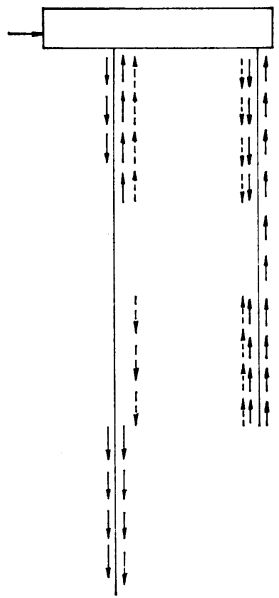

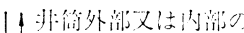
1 地盤尤的の摩擦力

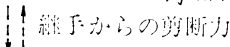
(a)

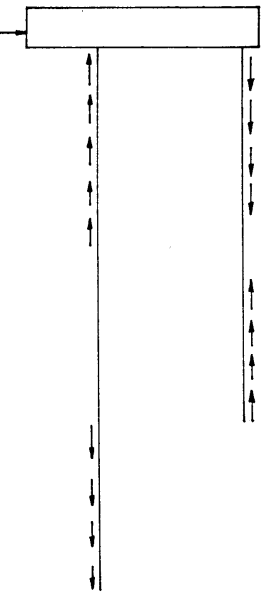

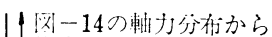
一推起した摩擦力 と䋛丁からの剪断力 の命少の作用方向

(b)

\section{図-15 摩擦力および継手からのせん断力の作用方向}

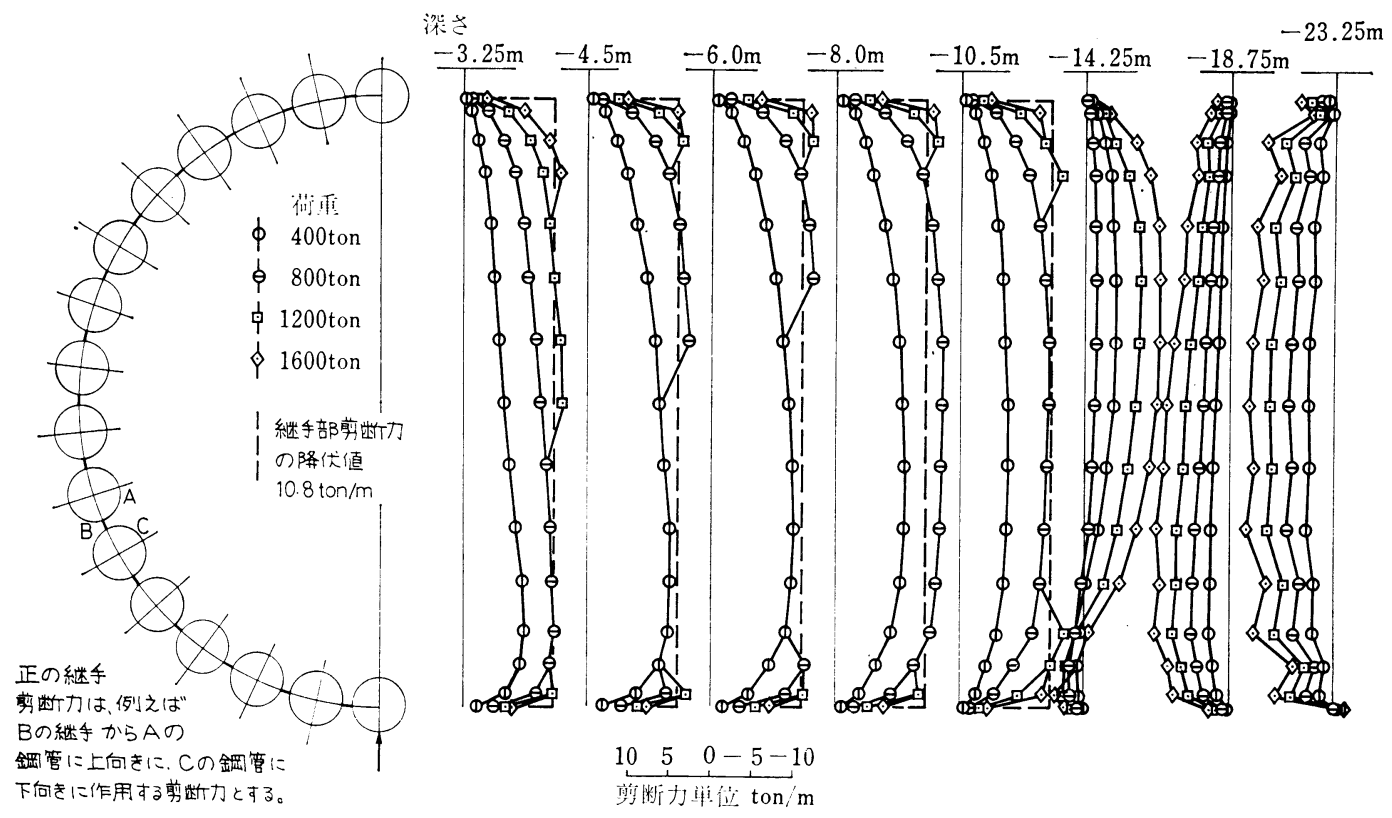

図一16 継手部のせん断力

（i ） 井筒の変形はせん断変形のあるはりの変形に類 似しており，変形前に中心軸に直交していた平面 は変形後中心軸と必ずしも直交しないが平面を保 っている (図一10 参照).

（ii） 井筒内部の土は鋼管群とほぼ同じ変位をし，井 筒と同じ上記の平面を保っている (図一11 参照).

(iii）鋼管の曲げモーメントは同一水平面上でほぼ一 様であり，鋼管位置によらない（図-12 参照).

さらに, 図一14 に示す各鋼管軸力の鉛直方向分布を, 同一水平面上の軸力分布にかきかえると，次の特性をあ げることができる.

(iv) 同一の水平面上で, 鋼管の軸力分布は鋼管の $x$ 座標の一次式である三角形分布に近い。ただし， 対称断面上の鋼管およびそれに隣接する鋼管につ いて，深さ $2.5 \mathrm{~m} \sim 7 \mathrm{~m}$ 間の軸力を除く.

駒田・岡原 ${ }^{1)}{ }^{2)}$ は (i) を前提条件とし, その結果 (iii), (iv)の特性を持つ線材モデルを提案している. 文献 1), 2) では前提条件の実験などによる検証は行われていな 


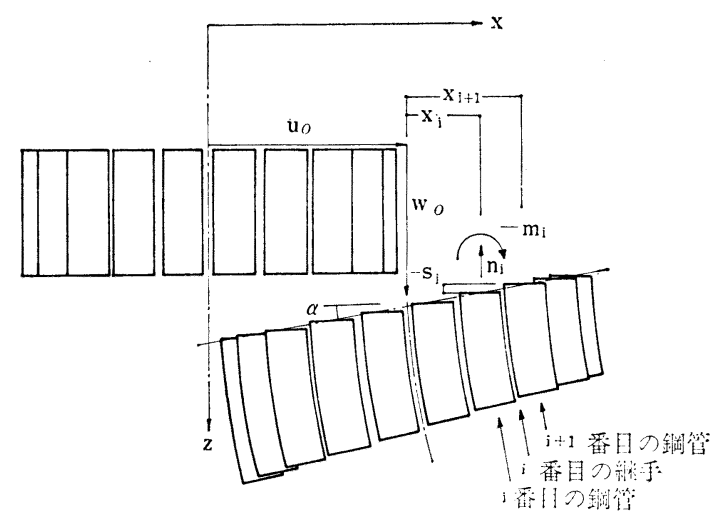

図一17鋼管矢板井筒の線材モデル

いが，本数值実験を一検証例とすることができよう。こ のモデルに対し，（ii）の井筒内部土の特性に基づいて 内部土のせん断剛性の影響を取り入れること，およびつ り合い式をたてる際の継手せん断剛性の取り入れ方をよ り明確にすることの 2 点の修正を行い，この修正モデル について以下簡単に説明する. 次いで, 修正モデルと現 行設計施工指針 ${ }^{3)}$ の関連, 合成効率の新しい力学的意味 等を示す.

図一17 に示すように井筒の中心軸にそって $z$ 軸, 直 交する方向に $x$ 軸, フーチング下面上に原点をとり, 井 筒の長さを $a$ とする. (i), (ii) の特性より井筒内部の 土および鋼管中心軸上の $x, z$ 方向の変位 $u, w$ を次の 形におく.

$$
u(x, z)=u_{0}(z), w(x, z)=w_{0}(z)-x \alpha(z)
$$

位置 $x=x_{i}$ にある $i$ 番目の鋼管の曲げモーメント $m_{i}$, 軸力 $n_{i}$ は, 断面積 $A_{i}$, 断面二次モーメント $I_{i}$, 鋼材 のヤング率 $E$ を用いて次式で表わされる.

$$
\left.\begin{array}{l}
n_{i}=E A_{i}[\partial w / \partial z]_{x=x_{i}}=E A_{i}\left(w_{0}^{\prime}-x_{i} \alpha^{\prime}\right) \\
m_{i}=-E I_{i}\left[\partial^{2} u / \partial z^{2}\right]_{x=x_{i}}=-E I_{i} u_{0}^{\prime \prime}
\end{array}\right\}
$$

ここに'は $z$ による常微分を示す. $i$ 番目および $i+1$ 番目の鋼管の間にある $i$ 番目の継手部に作用する単位長 さ当りのせん断力 $q_{i}$ と相対変位 $s_{i}$ (図一17 参照) はせ ん断剛性を $G$ とすると,

$$
q_{i}=G s_{i}, s_{i}=\left(u_{0}^{\prime}-\alpha\right)\left(x_{i+1}-x_{i}\right) \cdots \cdots(10 \cdot \mathrm{a}, \mathrm{b})
$$

図一2の継手のせん断試験において, 荷重 $P$ と相対変 位 $\delta$ の関係を直線で近似する時, せん断剛性 $G$ は次式 で与えられる.

$$
G=P / 2 L \delta
$$

位置 $(x, z)$ の井筒内部の土のせん断応力 $\tau_{x z}$, せん断ひ ずみ $\gamma_{x z}$ は，土のせん断弾性係数を $G_{s}$ とすると

$$
\tau_{x z}=G_{s} r_{x z}, r_{x z}=\partial u / \partial z+\partial w / \partial x=u_{0}^{\prime}-\alpha
$$

井筒内部の土の水平断面積を $A_{s}$, 井筒側面の $x$ 方向の ばね係数を $k(z)$ とすると, 仮想仕事式は次のとおりで ある・

$$
\begin{gathered}
\int_{0}^{a}\left\{\sum\left(n_{i}\left[\frac{\partial \delta w}{\partial z}\right]_{x=x_{i}}-m_{i}\left[\frac{\partial^{2} \delta u}{\partial z^{2}}\right]_{x=x_{i}}\right)\right. \\
\left.+\sum q_{i} \delta s_{i}+\iint_{A_{s}} \tau_{x y} \delta r_{x y} d A_{s}\right\} d z \\
\quad-\int_{0}^{a} k u_{0} \delta u_{0} d z-\left(\begin{array}{l}
\text { 井筒頭部および先 } \\
\text { 端での外力仕事 }
\end{array}\right) \\
=0
\end{gathered}
$$

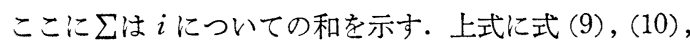
（12）を代入し，変分学の基本補題を適用すると次のつ り合い式を得る。

$$
\begin{aligned}
& \left(E w_{0} \sum A_{i}\right)^{\prime}=0 \\
& \left(E \alpha^{\prime} \sum A_{i} x_{i}^{2}\right)^{\prime}+\left\{G \sum\left(x_{i+1}-x_{i}\right)^{2}\right. \\
& \left.+G_{s} A_{s}\right\}\left(u_{0}^{\prime}-\alpha\right)=0 \\
& -\left(E u_{0}^{\prime \prime} \sum I_{i}\right)^{\prime \prime}+\left[\left\{G \sum\left(x_{i+1}-x_{i}\right)^{2}\right.\right. \\
& \left.\left.+G_{s} A_{s}\right\}\left(u_{0}^{\prime}-\alpha\right)\right]^{\prime}-k u_{0}=0
\end{aligned}
$$

文献 1)，2）のつり合い式とは式 $(14 \cdot b, c)$ の第 2 項の 係数 $G \sum\left(x_{i+1}-x_{i}\right)^{2}+G_{s} A_{s}$ のみが異なっている.

強度の $50 \%$ の力または応力で定義した $G$ および $G_{s}$ を用い $G_{s} A_{s} / G \sum\left(x_{i+1}-x_{i}\right)^{2}$ を解析例について求める 々, 粘土層上部で 0.01 , 下部で 0.05 であり, 井筒内部 の土のせん断剛性の影響は小さいことが闰われる.

式 $(14 \cdot \mathrm{b}, \mathrm{c})$ より $\alpha^{\prime}=\mu(z) u_{0}^{\prime \prime}$ とおくと,

$$
\left\{E\left(\sum I_{i}+\mu \sum A_{i} x_{i}^{2}\right) u_{0}^{\prime \prime}\right\}^{\prime \prime}+k u_{0}=0
$$

すなわち $\mu(z)$ は設計施工指針 ${ }^{3)}$ の合成効率に相当して いる. 式 (9) を用いると

$$
\mu(z)=\frac{\alpha^{\prime}}{u_{0}^{\prime \prime}}=\frac{\sum n_{i} x_{i}}{K \sum m_{i}}, \quad K=\frac{\sum A_{i} x_{i}^{2}}{\sum I_{i}}
$$

上式による合成効率 $(\mu)$ は各鋼管の軸力と曲げモーメン トより計算でき, 従来の合成効率 ${ }^{5}$,12),13) とは異なった新 しい力学的意味を示している.

\section{6. むすび}

三次元有限要素法を用い, 静的水平荷重をうける鋼管 矢板井筒の実験では明確にしにくい性状の一部を明らか にしている.特性のいくつかをのべると，

（1）井筒の変形はせん断変形のあるはりの変形に類 似しており, 変形前に中心軸に直交していた平面は変形 後も平面を保持している.

（2） 井筒内部の土は井筒と一体となって変位し, 井 筒と同じ上記の平面を保っている.

（3）同一水平面上の鋼管の曲げモーメントはほぼ一 様であり，鋼管の位置によらない.

（4）同一水平面上の鋼管の軸力分布は，一部分を除 
いて, 井筒中心を通る水平軸からの距離の一次式で与え られ，三角形分布で近似できる.

（5）継手のせん断降伏は比較的小荷重で始まり，広 範囲に広がる. 継手に作用する円周方向の引張力は耐力 よりはるかに小さい.

（6）変形性状はケーソンよりはむしろフーチング だ頭部を固められた群杭のそれに近い.

これらの特性より, 駒田・岡原のモデル ${ }^{1,2)}$ で用いら 礼てる未検証の前提条件が妥当であることを示して いる. 次いでこのモデルに基づいて内部の土のせん断剛 性は井筒の挙動にあまり影響を与えないことを示し, 設

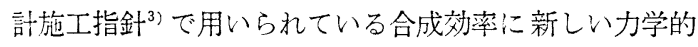
意味在与えている.

終りに，本論文についてご指導，ご討議いただいた関 西大学 山肩邦男教授, 数值計算にご努力いただいたセ ンチュリーリサーチ・センター（株）渡部巧一氏に感謝 の意を表する。

\section{参 考 文 献}

1）駒田敬一：矢板式基礎の構造特性，上木技術資料，1975.

2）駒田・岡原 : 欠板式基礎の構造解析法, 第 10 回土質工学 研究発表会講演集, pp. 549～552, 1975.

3）矢板式基礎研究委員会：矢板式基礎の設計と施工指針,
1972.

4) 長岡・吉田・榊：鋼管矢板井筒の有限要素振動解析々野 外実験結果との比較, 土木学会論文報告集, No. $245, \mathrm{pp}$. 61 72, 1976.

5）藤田・山口・木寺・島岡・小間：鋼管矢板井筒基礎の施 工および水平載荷試験, 士と基檚, Vol. 21, No. 12, pp. 9〜15, 1973.

6) Duncan, J.M. and C-Y. Chang: Nonlinear analysis of stress and strain in soils, Proc. of ASCE, Vol. 96, No. SM 5, pp. 1629 1653, 1970.

7) Kulhawy, F.H. and J.M. Duncan : Stresses and movements in Orovilledam, Proc. of ASCE, Vol. 98, No. SM 7, pp. 653 665, 1972.

8）藤田圭一：標準貫入試験，士質工学会編「土質調査試験 結果の鲢析之適用例」第 2 章, pp. 29〜 75, 1968.

9）中瀬明男 : 土のせえ断, 最上武雄編著「土質力学」第 5 章，技報堂，pp. 479 622, 1969.

10) Lambe, T.W. and R.V. Whitman : Soil Mechanics, John Wiley \& Sons, pp. 462 463, 1969.

11）横尾・山肩・長岡：支持ぐいの載荷試験における残留沈 下量曲楾の力学的意義, 日本建築学会論文報告集, No. 112, pp. 23 29, 1965.

12）嶋・加藤・斎藤 : 鋼管矢板井筒の剛性について，土木学 会第 25 回年㳄学術講演会講演集第 3 部, pp. $41 \sim 44$, 1970.

13）西垣 ·三笠・広部・加藤：鋼管矢板井筒の水平載荷試験 (II) 一地盤反力倸数と合成効率一, 第 7 回土質工学研究 発表会講演集, pp. 611 614, 1972.

(1976.3.24 · 受付) 